\title{
Late-onset of immunodysregulation, polyendocrinopathy, enteropathy, x-linked syndrome (IPEX) with intractable diarrhea
}

\author{
Daniele Zama ${ }^{1 *}$, llaria Cocchi ${ }^{1}$, Riccardo Masetti ${ }^{1}$, Fernando Specchia ${ }^{1}$, Patrizia Alvisi ${ }^{2}$, Eleonora Gambineri ${ }^{3,4}$, \\ Mario Lima ${ }^{5}$ and Andrea Pession ${ }^{1}$
}

\begin{abstract}
The syndrome of immune dysregulation, polyendocrinopathy, enteropathy, $X$ linked (IPEX) is a rare disorder caused by mutations in the FOXP3 gene. Diarrhea, diabetes and dermatitis are the hallmark of the disease, with a typical onset within the first months of life. We describe the case of a twelve-year old male affected by a very late-onset IPEX with intractable enteropathy, which markedly improved after starting Sirolimus as second-line treatment. This case suggests that IPEX should always be considered in the differential diagnosis of watery intractable diarrhea, despite its unusual onset.
\end{abstract}

Keywords: Immunodysregulation polyendocrinopathy enteropathy X-linked syndrome (IPEX), Sirolimus, Forkhead box P3 (FOXP3)

\section{Correspondence}

The syndrome of immune dysregulation, polyendocrinopathy, enteropathy, X-linked (IPEX) is a rare disorder, characterized by diarrhea, type- 1 diabetes mellitus (T1DM) and dermatitis with onset within the first months of life $[1,2]$. Diarrhea is intractable and persists despite dietary exclusions and bowel rest, resulting in malabsorption and failure to thrive [3]; T1DM can precede or follow enteritis [4-6]; dermatitis is severe with eczematiform, ichthyosiform or psoriasiform aspects [7-10], other autoimmune diseases are often associated [11].

IPEX is caused by germ-line mutations in the FOXP3 gene, a key regulator of immune tolerance, located in the

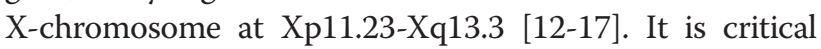
for the function of $\mathrm{CD} 4^{+} \mathrm{CD} 25^{+}$regulatory T-cells ( $\mathrm{T}_{\mathrm{REG}}$ ) and for the maintenance of peripheral immunologic tolerance $[17,18]$.

* Correspondence: daniele.zama@gmail.com

'Pediatric Oncology and Haematology Unit "Lalla Seràgnoli", Department of Pediatrics, University of Bologna Sant'Orsola-Malpighi Hospital, Via Massarenti, 11, Bologna 40138, Italy

Full list of author information is available at the end of the article

\section{Findings}

We describe a 12-year-old boy born at term from natural birth after an uncomplicated pregnancy from unrelated parents, referred to our hospital for severe enteritis started one month before with liquid mucus-haematic diarrhoea (height: $50^{\text {th }}$ centile, weight: $10^{\text {th }}$ centile, regularly vaccinated). No potentially triggering events have been reported, such as vaccinations, viral infections or changes in nutrition. In his past history he had recurring episodes of mild atopic dermatitis since the first year of life, a high level of total IgE (400 UI/L), and a constipated bowel (once every two/three days).

On admission, he was dehydrated (7\% of weight loss). Blood tests revealed hypoproteinaemia and hypogammaglobulinemia (Table 1), so albumin was replaced.

Abdominal ultrasound highlighted wall thickening of the bowel loops. Esophagogastroduodenoscopy (EGDS) and colonoscopy revealed ulcerative lesions at the stomach, duodenum, terminal ileum and colon, giving rise to a suspect of inflammatory bowel disease. Biopsies revealed villous blunting and inflammatory infiltration of the mucosa. After starting intravenous methylprednisolone, metronidazole and parenteral nutrition a partial remission was observed.

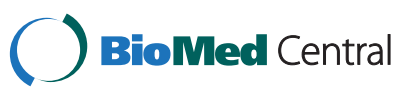

(c) 2014 Zama et al.; licensee BioMed Central Ltd. This is an Open Access article distributed under the terms of the Creative Commons Attribution License (http://creativecommons.org/licenses/by/4.0), which permits unrestricted use, distribution, and reproduction in any medium, provided the original work is properly credited. The Creative Commons Public Domain Dedication waiver (http://creativecommons.org/publicdomain/zero/1.0/) applies to the data made available in this article, unless otherwise stated. 
Table 1 The molecular and clinical features of the patient with IPEX who received sirolimus have been reported

\begin{tabular}{|c|c|c|c|c|c|c|c|c|c|c|c|c|}
\hline \multicolumn{2}{|c|}{ Patient } & \multicolumn{4}{|l|}{ Mutation } & \multirow[t]{2}{*}{ Clinical features } & \multirow[t]{2}{*}{ Histology } & \multicolumn{3}{|l|}{ Management } & \multirow[t]{2}{*}{ Outcome } & \multirow[t]{2}{*}{ Ref. } \\
\hline & $\begin{array}{l}\text { Age at onset } \\
\text { age at dg }\end{array}$ & $\begin{array}{l}\text { Nucleotide } \\
\text { change }\end{array}$ & $\begin{array}{l}\text { AA } \\
\text { change }\end{array}$ & FOXP3 & Molecular defect & & & Previous therapy & SIR & $\mathrm{HSCT}$ & & \\
\hline 1 & $\begin{array}{l}7 y \\
10 y\end{array}$ & $\begin{array}{l}c .968- \\
20 A>C\end{array}$ & NA & NA & NA & Dermatitis, enteropathy & $\begin{array}{l}\text { Lymphoplasmocellular } \\
\text { eosinophilic infiltrate. } \\
\text { Villous atrophy. }\end{array}$ & $\begin{array}{l}\text { Steroids, AZA, CsA, } \\
\text { FK, MTX. TPN, Total } \\
\text { colectomy at } 10 \text { y }\end{array}$ & Y & $\mathrm{N}$ & $\begin{array}{l}\text { Stable at } 16 \mathrm{yr} \\
\text { on SIR+MTX. }\end{array}$ & [19] \\
\hline $2^{*}$ & $\begin{array}{l}2 \mathrm{~m} \\
\mathrm{NA}\end{array}$ & NA & & & & $\begin{array}{l}\text { Enteropathy, } \\
\text { erythematous } \\
\text { eczema-like } \\
\text { dermatitis }\end{array}$ & $\begin{array}{l}\text { Lymphoplasmocellular } \\
\text { infiltrate with marked } \\
\text { eosinophilia. High rate } \\
\text { of enterocyte apoptosis. } \\
\text { Subtotal villous atrophy. }\end{array}$ & Steroids, FK, AZA & Y & $\mathrm{N}$ & $\begin{array}{l}\text { Stable for } 1.5 \mathrm{yr} \\
\text { on SIR+AZA }\end{array}$ & [19] \\
\hline $3^{*}$ & $\begin{array}{l}2 \mathrm{~m} \\
\mathrm{NA}\end{array}$ & NA & & & & $\begin{array}{l}\text { Enteropathy, } \\
\text { erythematous } \\
\text { eczema-like } \\
\text { dermatitis }\end{array}$ & $\begin{array}{l}\text { Similar findings with } \\
\text { that of his brother (pt.4) }\end{array}$ & Steroids, FK; AZA & Y & $\mathrm{N}$ & $\begin{array}{l}\text { Stable for } 6 \mathrm{~m} \\
\text { on SIR+AZA }\end{array}$ & [19] \\
\hline 4 & $\begin{array}{l}2 y \\
4 y\end{array}$ & 1061 delC & $\begin{array}{l}\text { Frameshift } \\
\text { P354Q }\end{array}$ & NA & $\begin{array}{l}\text { Premature stop } \\
\text { codon. Truncated } \\
\text { FKH domain }\end{array}$ & $\begin{array}{l}\text { Enteropathy, } \\
\text { nonspecific } \\
\text { dermatitis }\end{array}$ & Mild villous blunting & $\begin{array}{l}\text { Metronidazole, } \\
\text { steroids, mesalamine, } \\
\text { IFX, AZA, 6-MP }\end{array}$ & Y & $\mathrm{N}$ & Stable at $7 \mathrm{yr}$ & [20] \\
\hline 5 & $\begin{array}{l}1 w \\
7 y\end{array}$ & $200 G>T$ & $\mathrm{Q70H}$ & NA & $\begin{array}{l}\text { Predicted abnormal } \\
\text { reading frame }\end{array}$ & $\begin{array}{l}\text { Eczema, } \\
\text { enteropathy, } \\
\text { AHA, ITP, arthritis }\end{array}$ & $\begin{array}{l}\text { Inflammation with } \\
\text { villous atrophy }\end{array}$ & $\begin{array}{l}\text { IVIG, steroids, TPN, } \\
\text { antibiotics }\end{array}$ & Y & $\mathrm{N}$ & Stable at $8 \mathrm{yr}$ & {$[20,21]$} \\
\hline $6^{*}$ & $\begin{array}{l}3 w \\
\text { NA }\end{array}$ & $\begin{array}{l}\text { g.-6247- } \\
\text { 4859del }\end{array}$ & NA & $\downarrow$ & $\begin{array}{l}\text { Accumulation of } \\
\text { unspliced mRNA }\end{array}$ & $\begin{array}{l}\text { Skin/food } \\
\text { allergies, Enteropathy, } \\
\text { erythematous- } \\
\text { eczematous skin rash }\end{array}$ & $\begin{array}{l}\text { Lymphoplasmocellular } \\
\text { infiltrate with marked } \\
\text { eosinophilia. High } \\
\text { rate of enterocytes } \\
\text { apoptosis. Severe to } \\
\text { total villous atrophy }\end{array}$ & $\begin{array}{l}\text { Steroids, FK, } \\
\text { AZA TPN }\end{array}$ & Y & $\mathrm{N}$ & $\begin{array}{l}\text { Stable for } 6 \text { yr } \\
\text { on SIR+AZA }\end{array}$ & [22] \\
\hline $7^{*}$ & $\begin{array}{l}2 \mathrm{~m} \\
\mathrm{NA}\end{array}$ & $\begin{array}{l}\text { g.-6247- } \\
\text { 4859del }\end{array}$ & NA & $\downarrow$ & $\begin{array}{l}\text { Accumulation of } \\
\text { unspliced mRNA }\end{array}$ & $\begin{array}{l}\text { Skin/food allergies, } \\
\text { Eczema, Enteropathy }\end{array}$ & NA & $\begin{array}{l}\text { Steroids, FK, } \\
\text { AZA TPN }\end{array}$ & Y & $\mathrm{N}$ & $\begin{array}{l}\text { Stable for } 4 \text { yr } \\
\text { on SIR+AZA }\end{array}$ & [22] \\
\hline 8 & $\begin{array}{l}5 w \\
\text { NA }\end{array}$ & $\begin{array}{l}\text { g.-6247- } \\
\text { 4859del }\end{array}$ & NA & $\downarrow$ & $\begin{array}{l}\text { Accumulation of } \\
\text { unspliced mRNA }\end{array}$ & $\begin{array}{l}\text { Enteropathy, } \\
\text { Eczema, Allergy }\end{array}$ & NA & Steroids, FK, AZA & Y & $\mathrm{N}$ & $\begin{array}{l}\text { Stable at } 9 \mathrm{yr} \\
\text { on SIR+AZA }\end{array}$ & [23] \\
\hline 9 & $\begin{array}{l}3 w \\
\text { NA }\end{array}$ & $\begin{array}{l}\text { g.-6247- } \\
\text { 4859del }\end{array}$ & NA & $\downarrow$ & $\begin{array}{l}\text { Accumulation of } \\
\text { unspliced mRNA }\end{array}$ & $\begin{array}{l}\text { Enteropathy, } \\
\text { Eczema, HP } \\
\text { gastritis, Allergy }\end{array}$ & NA & Steroids, FK AZA & Y & $\mathrm{N}$ & $\begin{array}{l}\text { Stable at } 6 \text { yr } \\
\text { on SIR+AZA }\end{array}$ & [23] \\
\hline 10 & $\begin{array}{l}\text { Birth } \\
\text { NA }\end{array}$ & $\begin{array}{l}\text { g. }-1121 \\
T>G\end{array}$ & F374C & $\downarrow$ & $\begin{array}{l}\text { Full length FOXP3 } \\
\text { with abnormal } \\
\text { FKH domain }\end{array}$ & $\begin{array}{l}\text { T1DM, HTH, } \\
\text { Enteropathy, } \\
\text { Eczema, AHA, ITP, } \\
\text { Allergy. }\end{array}$ & NA & Steroids, FK506 & Y & $\mathrm{N}$ & $\begin{array}{l}\text { Died at } 14 \mathrm{~m} \\
\text { during } \mathrm{HSCT} \\
\text { induction }\end{array}$ & [23] \\
\hline 11 & $\begin{array}{l}6 w \\
\text { NA }\end{array}$ & $\begin{array}{l}\text { 751-753 } \\
\text { del GAG }\end{array}$ & E251del & $\downarrow$ & $\begin{array}{l}\text { Disrupts FOXP3 } \\
\text { oligomerisation }\end{array}$ & $\begin{array}{l}\text { Enteropathy, Eczema, } \\
\text { HTH, Interstitial } \\
\text { Nephritis, AHA, Allergy. }\end{array}$ & NA & FK506 & Y & Y & $\begin{array}{l}\text { Died at } 10 \mathrm{yr} \\
\text { after HSCT }\end{array}$ & [23] \\
\hline 12 & $\begin{array}{l}1 \mathrm{~m} \\
6 \mathrm{y}\end{array}$ & $1150 G>A$ & A384T & $\downarrow$ & $\begin{array}{l}\text { Full length FOXP3 } \\
\text { with abnormal } \\
\text { FKH domain }\end{array}$ & $\begin{array}{l}\text { Enteropathy, Eczema, } \\
\text { FTT, T1DM, AHA, } \\
\text { Interstitial Pneumonia, } \\
\text { Alopecia, Thyroiditis. }\end{array}$ & $\begin{array}{l}\text { Eosinophil infiltration } \\
\text { without villous atrophy }\end{array}$ & $\begin{array}{l}\text { IVIG, CSA, steroids, } \\
\text { TPN, fludarabine-autologous } \\
\text { lymphocytes, FK, MTX, } \\
\text { Rituximab, cyclophosphamide. }\end{array}$ & Y & $N$ & $\begin{array}{l}\text { Stable at } 16 \mathrm{yr} \\
\text { on others } \\
\text { drugs }\end{array}$ & {$[4,24,25]$} \\
\hline
\end{tabular}


Table 1 The molecular and clinical features of the patient with IPEX who received sirolimus have been reported (Continued)

\begin{tabular}{|c|c|c|c|c|c|c|c|c|c|c|c|c|}
\hline 13 & $\begin{array}{l}\text { Birth } \\
7 w\end{array}$ & $1150 G>A$ & A384T & $\downarrow$ & $\begin{array}{l}\text { Full length FOXP3 with } \\
\text { abnormal FKH domain }\end{array}$ & $\begin{array}{l}\text { Enteropathy, T1DM, } \\
\text { Exfoliative Dermatitis, } \\
\text { HTH, Pancytopenia }\end{array}$ & NA & TPN & Y & $\mathrm{N}$ & Died at $7 \mathrm{w}$ & {$[26]$} \\
\hline 14 & $\begin{array}{l}\text { Birth } \\
41 / 2 y\end{array}$ & $\begin{array}{l}\text { AAUAAA } \\
\text { AAUAAG }\end{array}$ & NA & $\downarrow$ & $\begin{array}{l}\text { Polyadenylation defect } \\
\text { resulting in unstable } \\
\text { FOXP3 mRNA }\end{array}$ & $\begin{array}{l}\text { Enteropathy, Dermatitis, } \\
\text { FTT, T1D. }\end{array}$ & NA & MTX, steroids, TPN. & Y & Y & Stable at $1 \mathrm{yr}$ & {$[27]$} \\
\hline 15 & $1 \mathrm{w}$ & $1015 C>G$ & P339A & $\downarrow$ & $\begin{array}{l}\text { Missense mutation. } \\
\text { Predicted to yield full } \\
\text { length FOXP3 }\end{array}$ & $\begin{array}{l}\text { Enteropathy, Eczema, } \\
\text { T1DM, FTT, Euthyroid } \\
\text { Thyroiditis, AlH, AHA }\end{array}$ & Villous atrophy & Steroids, FK; AZA & Y & $\mathrm{N}$ & $\begin{array}{l}\text { Died at } 5.5 \mathrm{~m} \\
\text { before HSCT }\end{array}$ & [28] \\
\hline 16 & $\begin{array}{l}3 \mathrm{~m} \\
1 \mathrm{y}\end{array}$ & Exon 10 & NA & NA & NA & $\begin{array}{l}\text { FTT, Enteropathy, } \\
\text { Eczematous Dermatitis, } \\
\text { ITP stomatitis }\end{array}$ & NA & $\begin{array}{l}\text { Cyclophosphamide, } \\
\text { VCR, TPN }\end{array}$ & $Y$ & $\mathrm{~N}$ & $\begin{array}{l}\text { Stable } 2 \frac{1}{2} \text { yr } \\
\text { on other drugs }\end{array}$ & [29] \\
\hline
\end{tabular}

"Brothers; 6-MP 6-Mercaptopurina; AHA autoimmune haemolytic anaemia; AlH Autoimmune hepatits; AZA Azathioprine; CsA Cyclosposporine; FTT: failure to thrive; FK: tacrolimus; HSCT hematopoietic stem cell transplantation; HTH Hypothyroidism; IFX Infliximab; ITP immune thrombocytopenic purpura; IVIG Intravenous Immunoglobulin; Y: Yes; yr: years; m: months; MTX Methotrexate; NA Not Available; N: No; Ref. References; SIR Sirolimus; T1DM Type 1 Diabetes mellitus; TPN Total Parenteral Nutrition; VCR Vincristine; w: weeks; l: reduction of expression. 
Ten days later, for a worsening of symptoms, EGDS and colonoscopy were repeated, with a superimposable picture. Particularly, the biopsies of the colon showed lympho-granulocytic acute inflammation with Graft versus Host Disease-like aspect, a lesion typically reported in IPEX (Figure 1) [30]. Due to the inability to control the symptoms the patient underwent ileostomy.

Despite the age of the patient was atypical for the onset of IPEX, we evaluated the presence of autoantibodies to harmonin, which resulted positive (>100 U.A.). Then, diagnosis was confirmed by the genetic examination of FOXP3 gene, revealing a mutation in the exon 9 (1040G > A), with substitution of Arginine to Histidine $(\mathrm{R} 347 \mathrm{H})$. The mother resulted negative. The total number of lymphocyte and lymphocyte subpopulations was normal, particularly $\mathrm{T}_{\text {REG }}$ were $5 \%$ of the total number.

Intravenous cyclosporine (range: $200-350 \mathrm{mg} / \mathrm{dl}$ ) and methylprednisolone $(2 \mathrm{mg} / \mathrm{kg}$ ) were started, which reduced diarrhea and abdominal pain. After sixty days of parenteral nutrition the patient returned to oral feeding with the normalization of albumin levels (Table 1). Because of the onset of post-prandial hyperglycaemias, we excluded T1DM (Table 1) and glycaemia normalized after tapering steroid therapy. For a new worsening of the disease we introduced sirolimus $(0.15 \mathrm{mg} / \mathrm{kg} /$ day; range: $8-12 \mathrm{mg} / \mathrm{dl})$. The patient improved with a progressive reduction of intensity and frequency of abdominal pain and mucus emission. A new colonoscopy highlighted a marked decrease of the inflammation. After thirty-four days since the beginning of sirolimus, cyclosporine was suspended. After twelve months the patient is well, without recurrence of the disease.

\section{Conclusions}

This case indicates that IPEX can have an atypical age of presentation. Thus, it should always be considered in the differential diagnosis of intractable diarrhea.

Four patients have been previously reported with IPEX with the same amino-acid substitution (R347H) found in our patient. The age of onset for all these subjects was within the first year of life and the first symptoms were recurrent ear infection, high IgE levels, T1DM, and gastritis. All had gastrointestinal symptoms with failure to thrive: two intractable diarrhea, two severe gastritis with mucosal atrophy or eosinophilic infiltration. Other symptoms were: coombs-negative haemolytic anaemia, food allergy, pancreatic exocrine failure, intractable hypertension, intestinal metaplasia, steatorrhea, and hypogammaglobulinemia. Patients received corticosteroid and calcineurin inhibitors. One patient died after allogeneic hematopoietic stem cell transplantation (HSCT) due to an infection.

Recently, evidence that patients with a severe form of IPEX may have circulating $\mathrm{FOXP3}^{+} \mathrm{T}$ cells, as it is the case of our patient, which suggests that the cellular basis for the disease may be a result of a functional defect of Treg cells [1,26]. Mainly, R347H mutated-FOXP3 has been demonstrated as effective as wild-type-FOXP3 in converting normal $\mathrm{T}$ cell into Treg in vitro [31] and in maintaining the ability to suppress the production of cytokines, hallmark of Treg cells, conferring suppressive capacity on $\mathrm{CD}_{4}^{+} \mathrm{T}$ cells.

In 2005, three patients were successfully treated with sirolimus [19]. Since then, 16 patients received sirolimus and nine are in complete or partial remission (Table 2).
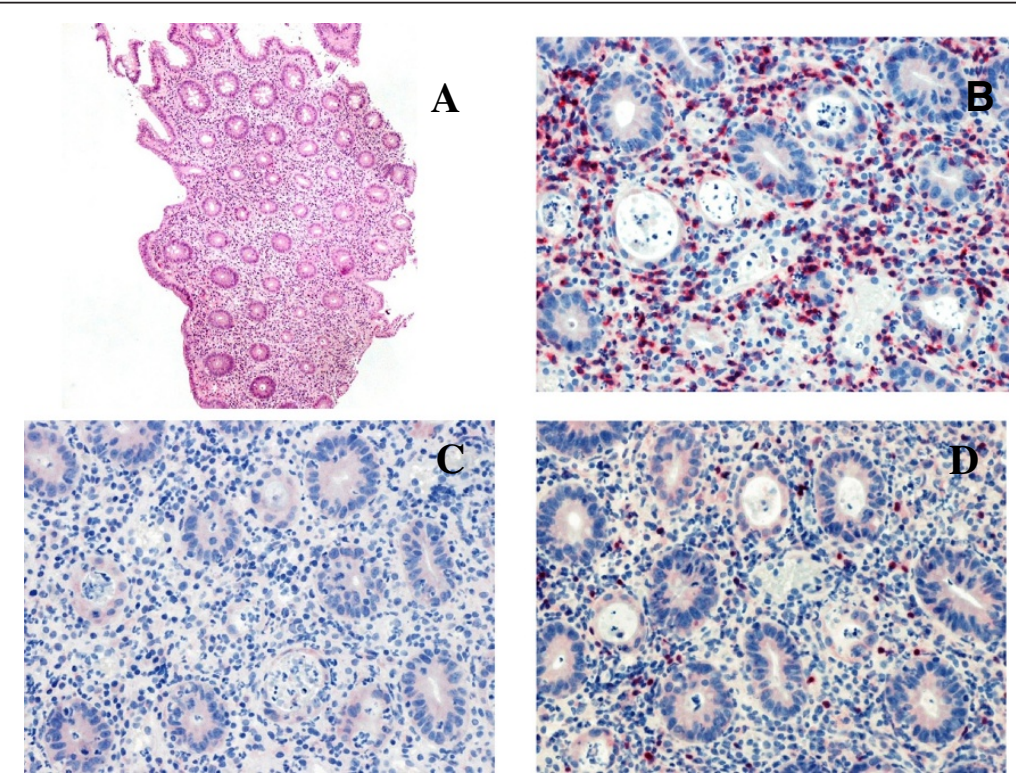

Figure 1 Biopsy of the colon mucosa highlights a marked inflammatory infiltrate. (A: H\&E 5x) with a GVHD-like aspect characterized by a prevalence of lymphocytes CD8+ (red; B) than lymphocytes CD4+ (red; C). Rare lymphocytes expressing FOXP3 were found (red; D). 
Table 2 Variables of our patient at the time of admission to our hospital, when he started the second line therapy with Sirolimus and after three months since the begging of this therapy

\begin{tabular}{|c|c|c|c|c|}
\hline Variables & Reference range, age and sex-adjusted & Admission & Start SIROLIMUS & 3 months after SIROLIMUS \\
\hline White-cell count - per $\mathrm{mm}^{3}$ & $4.5-13.5$ & 15.01 & 4.04 & 5.01 \\
\hline Hemoglobin $-g / d l$ & $11.5-14.5$ & 16.3 & 11.7 & 11.5 \\
\hline Hematocrit —\% & $35-42$ & 46.0 & 34.4 & 35.7 \\
\hline \multicolumn{5}{|l|}{ Differential count —\% } \\
\hline Neutrophils & $40.0-74.0$ & 89.6 & 51.2 & 48.0 \\
\hline Lymphocytes & $19.0-48.0$ & 6.6 & 30.3 & 38.0 \\
\hline Monocytes & $3.0-9.0$ & 2.4 & 13.5 & 7.6 \\
\hline Eosinophils & $0.0-6.0$ & 0.4 & 1.7 & 4.4 \\
\hline Basophils & $0.0-1.5$ & 0.3 & 1.1 & 0.7 \\
\hline Platelet count - per $\mathrm{mm}^{3}$ & $250-550$ & 522 & 247 & 273 \\
\hline Glucose - mg/dl & $60-100$ & 125 & 107 & 77 \\
\hline Insulinemia - microU/mL & $7-24$ & & 6.8 & \\
\hline C-peptide $-\mathrm{ng} / \mathrm{mL}$ & $1.1-4.4$ & & 2.7 & \\
\hline Islet cell autoantibodies & Neg & & Neg & Neg \\
\hline \multirow[t]{2}{*}{ Glutamic acid decarboxylase- $\mathrm{UI} / \mathrm{ml}$} & $<10 \mathrm{Neg}$ & & Neg & Neg \\
\hline & $>10$ Pos & & & \\
\hline UREA - mg/dl & $15-50$ & 72 & 40 & 18 \\
\hline Creatinine $-\mathrm{mg} / \mathrm{dl}$ & $0.5-1$ & 0.91 & 0.54 & 0.35 \\
\hline Uric Ac. - mg/dl & $2.2-6.6$ & 8.6 & 5.2 & 3.4 \\
\hline Total Colesterol $-\mathrm{mg} / \mathrm{dl}$ & $130-204$ & & 121 & \\
\hline $\mathrm{TG}-\mathrm{mg} / \mathrm{dl}$ & $31-108$ & & 40 & \\
\hline $\mathrm{HDL}-\mathrm{mg} / \mathrm{dl}$ & $>35$ & & 62 & \\
\hline $\mathrm{LDL}-\mathrm{mg} / \mathrm{dl}$ & $<170$ & & 50 & \\
\hline \multicolumn{5}{|l|}{ Electrolytes - mmol/L } \\
\hline Sodium & $136-146$ & 128 & 139 & 142 \\
\hline Potassium & $3.5-5.3$ & 5.5 & 4.3 & 4.3 \\
\hline Chlorine & $98-106$ & 85 & 103 & 105 \\
\hline Calcium & $8.8-10.8$ & 9.6 & 9.3 & 9.2 \\
\hline Phosphorus - mg/dl & $2.9-5.4$ & 7.6 & 5 & 4.4 \\
\hline Magnesium - mg/dl & $1.6-2.6$ & 2.2 & 1.6 & 2.1 \\
\hline Plasma Osmolarity - mOsm/L & $278-305$ & 266 & & \\
\hline \multicolumn{5}{|l|}{ Protein - g/dl } \\
\hline Total & $6,4-8.1$ & 4.1 & 6.2 & 6.7 \\
\hline Albumin & $3.5-5$ & 2.4 & 4.2 & 4.3 \\
\hline y-Globulin —\% & $11.1-18.8$ & 10.5 & 11.4 & 13.4 \\
\hline \multicolumn{5}{|l|}{ Bilirubin $-\mathrm{mg} / \mathrm{dl}$} \\
\hline Total & $0.20-1.10$ & 1.54 & 0.44 & 0.3 \\
\hline Direct/Indirect & $0.00-0.30 /<0.80$ & $0.48 / 1.06$ & $0.21 / 0.23$ & $0.1 / 0.2$ \\
\hline AST/ALT - U/L & $<38 /<41$ & $44 / 34$ & $16 / 10$ & $22 / 17$ \\
\hline Total Amylase - U/L & $30-100$ & 50 & 60 & \\
\hline Iron $-\mu \mathrm{g} / \mathrm{dl}$ & $53-119$ & & 47 & 52 \\
\hline U.I.B.C./T.I.B.C. $-\mu \mathrm{g} / \mathrm{dl}$ & $110-330 / 250-400$ & & $300 / 347$ & $273 / 325$ \\
\hline
\end{tabular}


Table 2 Variables of our patient at the time of admission to our hospital, when he started the second line therapy with Sirolimus and after three months since the begging of this therapy (Continued)

\begin{tabular}{|c|c|c|c|c|}
\hline Ferritin $-\mathrm{ng} / \mathrm{mL}$ & $7-140$ & & 22 & 16 \\
\hline $\mathrm{TSH}-\mathrm{microU} / \mathrm{mL}$ & $0.6-6.3$ & & 1.93 & 1.02 \\
\hline $\mathrm{FT} 3-\mathrm{pg} / \mathrm{mL}$ & $2.5-5.5$ & & 3.6 & 4.1 \\
\hline $\mathrm{FT} 4-\mathrm{pg} / \mathrm{mL}$ & $9.0-17.0$ & & 20.7 & 12.9 \\
\hline ATA $-U I / m L$ & $<115$ & & 23 & 16 \\
\hline Anti TPO Ab - UI/mL & $<34$ & & 12 & 13 \\
\hline $\mathrm{ESR}-\mathrm{mm}$ & $<15$ & 6 & 15 & 9 \\
\hline $\mathrm{CRP}-\mathrm{mg} / \mathrm{dl}$ & $<0.5$ & 0.05 & 2.05 & 0.09 \\
\hline \multirow[t]{2}{*}{$A b$ anti harmonine IgG - U.A. } & $<3.0$ absent & & \multirow{2}{*}{$>100$} & \\
\hline & $>0.3$ present & & & \\
\hline ANA & $<1: 80$ & & $<1: 80$ & \\
\hline AMA & $<1: 40$ & & $<1: 40$ & \\
\hline \multirow[t]{3}{*}{ ENA } & $<0,7 \mathrm{Neg}$ & & Neg & \\
\hline & $0.7-1-0 \mathrm{Bl}$ & & & \\
\hline & $>1.0$ Pos & & & \\
\hline
\end{tabular}

ALT Alanine aminotransferase, AMA Anti-mitochondrial antibodies, ANA Antinuclear antibodies, anti-TPO Ab Anti-ThyroidPeroxidase Antibodies, AST aspartate aminotransferase, ATA Anti-Thyroglobulin Antibodies, BI Borderline, CRP C-reactive protein, ENA Extractable Nuclear Antigens, ESR erythrocyte sedimentation rate, FT3 Free Triiodothyronine, FT4 Free Thyroxine, HDL High-Density Lipoprotein, LDL Low-Density Lipoprotein, Neg Negative, Pos Positive, T.I.B.C. Total iron-binding capacity, TG triglycerides, TSH Thyroid-Stimulating Hormone, U.I.B.C. Unsaturated Iron Binding Capacity.

Considering that sirolimus seems to be as effective as the calcineurin inhibitors, with less toxic effects, it can be considered as a valid therapeutic option for bringing these patients to HSCT in their best clinical condition.

\section{Consent}

Written informed consent was obtained from the parents of the patient for publication of this Case report and any accompanying images. A copy of the written consent is available for review by the Editor-in-Chief of this journal.

\section{Ethical approval}

Internal ethical committee of Sant-Orsola approved the study.

\section{Abbreviations}

IPEX: Syndrome of immune dysregulation, polyendocrinopathy, enteropathy, X linked; T1DM: Type-1 diabetes mellitus; EGDS: Esophagogastroduodenoscopy; FKH: Forkhead/winged helix domain; mTOR: Mammalian target of rapamycin; HSCT: Hematopoietic stem cell transplantation.

\section{Competing interests}

The authors declare that they have no competing interests.

\section{Authors' contributions}

ZD and IC reviewed relevant articles on the literature, collected all the patient's data and drew the manuscript. FS and PA contributed to the diagnosis and provided clinical assistance. RM, ML and AP contributed to the conception and design, and revisited critically the manuscript. EG carried out the molecular genetic studies and drafted the manuscript. All authors read and approved the final manuscript.

\section{Author details}

'Pediatric Oncology and Haematology Unit "Lalla Seràgnoli", Department of Pediatrics, University of Bologna Sant'Orsola-Malpighi Hospital, Via Massarenti,
11, Bologna 40138, Italy. ${ }^{2}$ Pediatric Department, Maggiore Hospital, Bologna, Italy. ${ }^{3}$ Department of 'NEUROFARBA', Section of Child's Health, University of Florence, Florence, Italy. ${ }^{4}$ BMT Unit, Department of Hematology-Oncology, Anna Meyer Children's Hospital, Florence, Italy. ${ }^{5}$ Department of Pediatric Surgery, University of Bologna, Bologna, Italy.

Received: 17 April 2014 Accepted: 7 July 2014

Published online: 18 October 2014

\section{References}

1. Bacchetta R, Passerini L, Gambineri E, Dai M, Allan SE, Perroni L, DagnaBricarelli F, Sartirana C, Matthes-Martin S, Lawitschka A, Azzari C, Ziegler SF, Levings MK, Roncarolo MG: Defective regulatory and effector T cell functions in patients with FOXP3 mutations. J Clin Invest 2006, 116:1713-1722.

2. Wildin RS, Smyk-Pearson S, Filipovich AH: Clinical and molecular features of the immunodysregulation, polyendocrinopathy, enteropathy, $\mathrm{X}$ linked (IPEX) syndrome. J Med Genet 2002, 39:537-545.

3. Vliet HJJ Van D, Nieuwenhuis EE: IPEX as a Result of Mutations in FOXP3. Clin Dev Immunol 2007, 2007:3-8.

4. Gambineri E, Perroni L, Passerini L, Bianchi L, Doglioni C: Clinical and molecular profile of a new series of patients with immune dysregulation, polyendocrinopathy, enteropathy, X-linked syndrome: Inconsistent correlation between forkhead box protein 3 expression and disease severity. J Allergy Clin Immunol 2008, 122:1105-1113.

5. Peake JE, McCrossin RB, Byrne G, Shepherd R: X-linked immune dysregulation, neonatal insulin dependent diabetes, and intractable diarrhoea. Arch Dis Child Fetal Neonatal Ed 1996, 74:F195-F199.

6. Baud O, Goulet O, Canioni D, Le Deist F, Radford I, Rieu D, Dupuis-Girod S, Cerf-Bensussan N, Cavazzana-Calvo M, Brousse N, Fischer A, Casanova JL: Treatment of the immune dysregulation, polyendocrinopathy, enteropathy, X-linked syndrome (IPEX) by allogeneic bone marrow transplantation. N Engl J Med 2001, 344:1758-1762.

7. Ruemmele FM, Moes N, de Serre NP-M, Rieux-Laucat F, Goulet O: Clinical and molecular aspects of autoimmune enteropathy and immune dysregulation, polyendocrinopathy autoimmune enteropathy X-linked syndrome. Curr Opin Gastroenterol 2008, 24:742-748.

8. Nieves DS, Phipps RP, Pollock SJ, Ochs HD, Zhu Q, Scott GA, Ryan CK, Kobayashi I, Rossi TM, Goldsmith LA: Dermatologic and immunologic 
findings in the immune dysregulation, polyendocrinopathy, enteropathy, X-linked syndrome. Arch Dermatol 2004, 140:466-472.

9. De Benedetti F, Insalaco A, Diamanti A, Cortis E, Muratori F, Lamioni A, Carsetti R, Cusano R, De Vito R, Perroni L, Gambarara M, Castro M, Bottazzo GF, Ugazio AG: Mechanistic associations of a mild phenotype of immunodysregulation, polyendocrinopathy, enteropathy, x-linked syndrome. Clin Gastroenterol Hepatol 2006, 4:653-659.

10. Halabi-Tawil M, Ruemmele FM, Fraitag S, Rieux-Laucat F, Neven B, Brousse N, De Prost Y, Fischer A, Goulet O, Bodemer C: Cutaneous manifestations of immune dysregulation, polyendocrinopathy, enteropathy, X-linked (IPEX) syndrome. Br J Dermatol 2009, 160:645-651.

11. Torgerson TR: Regulatory T cells in human autoimmune diseases. Springer Semin Immunopathol 2006, 28:63-76.

12. Bennett CL, Christie J, Ramsdell F, Brunkow ME, Ferguson PJ, Whitesell L, Kelly TE, Saulsbury FT, Chance PF, Ochs HD: The immune dysregulation, polyendocrinopathy, enteropathy, X-linked syndrome (IPEX) is caused by mutations of FOXP3. Nat Genet 2001, 27:20-21.

13. Wildin RS, Ramsdell F, Peake J, Faravelli F, Casanova JL, Buist N, Levy-Lahad E, Mazzella M, Goulet O, Perroni L, Bricarelli FD, Byrne G, McEuen M, Proll S, Appleby M, Brunkow ME: X-linked neonatal diabetes mellitus, enteropathy and endocrinopathy syndrome is the human equivalent of mouse scurfy. Nat Genet 2001, 27:18-20.

14. Chatila TA, Blaeser F, Ho N, Lederman HM, Voulgaropoulos C, Helms C, Bowcock AM: JM2, encoding a fork head-related protein, is mutated in X-linked autoimmunity-allergic disregulation syndrome. J Clin Invest 2000, 106:R75-R81.

15. Marson A, Kretschmer K, Frampton GM, Jacobsen ES, Polansky JK, Maclsaac KD, Levine SS, Fraenkel E, von Boehmer H, Young RA: Foxp3 occupancy and regulation of key target genes during T-cell stimulation. Nature 2007, 445:931-935.

16. Zheng Y, Josefowicz SZ, Kas A, Chu T-T, Gavin MA, Rudensky AY: Genomewide analysis of Foxp3 target genes in developing and mature regulatory $T$ cells. Nature 2007, 445:936-940.

17. Wu Y, Borde M, Heissmeyer V, Feuerer M, Lapan AD, Stroud JC, Bates DL, Guo L, Han A, Ziegler SF, Mathis D, Benoist C, Chen L, Rao A: FOXP3 controls regulatory $T$ cell function through cooperation with NFAT. Cell 2006, 126:375-387.

18. Bettelli E, Dastrange M, Oukka M: Foxp3 interacts with nuclear factor of activated T cells and NF-kappa B to repress cytokine gene expression and effector functions of T helper cells. Proc Natl Acad Sci U S A 2005, 102:5138-5143.

19. Bindl L, Torgerson T, Perroni L, Youssef N, Ochs HD, Goulet O, Ruemmele FM: Successful use of the new immune-suppressor sirolimus in IPEX (immune dysregulation, polyendocrinopathy, enteropathy, X-linked syndrome). J Pediatr 2005, 147:256-259.

20. Yong PL, Russo P, Sullivan KE: Use of sirolimus in IPEX and IPEX-like children. J Clin Immunol 2008, 28(5):581-587.

21. Heltzer ML, Choi JK, Ochs HD, Sullivan KE, Torgerson TR, Ernst LM: A potential screening tool for IPEX syndrome. Pediatr Dev Pathol 2007, 10(2):98-105.

22. Torgerson TR, Linane A, Moes N, Anover S, Mateo V, Rieux-Laucat F, Hermine O, Vijay S, Gambineri E, Cerf-Bensussan N, Fischer A, Ochs HD, Goulet O, Ruemmele FM: Severe food allergy as a variant of IPEX syndrome caused by a deletion in a noncoding region of the FOXP3 gene. Gastroenterology 2007, 132:1705-1717.

23. Moes N, Rieux-Laucat F, Begue B, Verdier J, Neven B, Patey N, Torgerson $T$, Picard C, Stolzenberg M-C, Ruemmele C, Rings EH, Casanova J-L, Piloquet H, Biver A, Breton A, Ochs HD, Hermine O, Fischer A, Goulet O, Cerf-Bensussan $\mathrm{N}$, Ruemmele FM: Reduced expression of FOXP3 and regulatory T-cell function in severe forms of early-onset autoimmune enteropathy. Gastroenterology 2010, 139:770-778.

24. Hennezel E, Bin DK, Torgerson T, Piccirillo C: The immunogenetics of immune dysregulation, polyendocrinopathy, enteropathy, $\mathrm{X}$ linked (IPEX) syndrome. J Med Genet 2012, 49:291-302.

25. Taddio A, Faleschini E, Valencic E, Granzotto M, Tommasini A, Lepore L, Andolina M, Barbi E, Ventura A: Medium-term survival without haematopoietic stem cell transplantation in a case of IPEX: insights into nutritionaland immunosuppressive therapy. Eur J Pediatr 2007, 166(11):1195-1197.

26. d'Hennezel E, Ben-Shoshan M, Ochs HD, Torgerson TR, Russell L, Lejtenyi C, Noya FJ, Jabado N, Mazer B, Piccirillo CA: FOXP3 forkhead domain mutation and regulatory T cells in the IPEX syndrome. N Engl J Med 2009, 361:1710-1713.
27. Dorsey MJ, Petrovic A, Morrow MR, Dishaw LJ, Sleasman JW: FOXP3 expression following bone marrow transplantation for IPEX syndrome after reduced-intensity conditioning. Immunol Res 2009, 44:179-184.

28. Rubio-Cabezas O, Minton JAL, Caswell R, Shield JP, Deiss D, Sumnik Z, Cayssials A, Herr M, Loew A, Lewis V, Ellard S, Hattersley AT: Clinical heterogeneity in patients with FOXP3 mutations presenting with permanent neonatal diabetes. Diabetes Care 2009, 32:111-116.

29. Lucas KG, Ungar D, Comito M, Groh B: Epstein Barr virus induced lymphoma in a child with IPEX syndrome. Pediatr Blood Cancer 2008, 50:1056-1057.

30. Patey-Mariaud de Serre N, Canioni D, Ganousse S, Rieux-Laucat F, Goulet O, Ruemmele F, Brousse N: Digestive histopathological presentation of IPEX syndrome. Mod Pathol 2009, 22:95-102.

31. McMurchy AN, Gillies J, Allan SE, Passerini L, Gambineri E, Roncarolo MG, Bacchetta R, Levings MK: Point mutants of forkhead box P3 that cause immune dysregulation, polyendocrinopathy, enteropathy, X-linked have diverse abilities to reprogram $T$ cells into regulatory $T$ cells. J Allergy Clin Immunol 2010, 126:1242-1251.

\section{doi:10.1186/s13052-014-0068-4}

Cite this article as: Zama et al:: Late-onset of immunodysregulation, polyendocrinopathy, enteropathy, $x$-linked syndrome (IPEX) with intractable diarrhea. Italian Journal of Pediatrics 2014 40:68.

\section{Submit your next manuscript to BioMed Central and take full advantage of:}

- Convenient online submission

- Thorough peer review

- No space constraints or color figure charges

- Immediate publication on acceptance

- Inclusion in PubMed, CAS, Scopus and Google Scholar

- Research which is freely available for redistribution 